\title{
Iowa City Bound: Mormon Migration by Sail and Rail, 1856-1857
}

\author{
FRED E. WOODS
}

IN THE SPRING OF 1855, an article in the Mormons' British periodical, The Latter-day Saints' Millennial Star, instructed church members to leave "Babylon" just as ancient Israel had left Egypt under Moses' leadership. ${ }^{1}$ For European converts, the Atlantic was their Red Sea and Brigham Young their American Moses. During his nearly 30 years (1847-1877) as president and prophet of the Latter-day Saints (LDS), Young directed the organized migration of more than 70,000 people to Utah, most of them from Europe. He approved yearly migration plans, appointed officers to manage the various companies, and arranged for church agents to assist at ports and posts that dotted migration routes. His concern was to ensure converts the best rates and safest journey possible while traveling aboard sailing ships, riverboats, and railroad trains to the Great Salt Lake Valley. ${ }^{2}$

One example of Brigham Young's careful management of Mormon travel occurred in response to the epidemic of yellow fever and cholera that killed thousands of the general public traveling on the Mississippi River. On August 2, 1854, he sent a

1. "The Gathering," Millennial Star 18 (3/1/1856), 138.

2. For an excellent treatment of the routes, mode of operation, and general history of Mormon emigration from 1840 to 1855 (when the eastern ports began to be used), see Frederick Piercy, Route From Liverpool to Great Salt Lake Valley Illustrated with Steel Engravings and Wood Cuts from Sketches Made by Frederick Piercy, ed. James Linforth (Liverpool, 1855).

THE ANNALS OF IOWA 65 (Spring/Summer 2006). (C) The State Historical Society of Iowa, 2006. 
letter to Mormon Elder Franklin D. Richards, who had charge of Mormon emigration from Liverpool, with the counsel, "You are aware of the sickness liable to assail our unacclimated brethren on the Mississippi river, hence I wish you to ship no more to New Orleans, but ship to Philadelphia, Boston, and New York, giving preference in the order named." 3

This shift to the eastern seaboard was timely. In the spring of 1854, the Millennial Star had made a special appeal to "all who have the means to get to the States. ... Let nothing deter ... and let those who have not yet funds seek diligently to obtain them by every honourable method. Let no effort, no exertion be wanting." 4 At the same time, America's rail lines were quickly extending westward. By 1856 Iowa City boasted the farthest railhead west, and Brigham Young was determined to take advantage of that development. ${ }^{5}$ In 1856 and 1857 thousands of European Latter-day Saint converts poured through the ports of Philadelphia, Boston, and New York and on to booked railroad cars. After arriving in Iowa City, they secured handcarts or wagons and were assigned to an overland trail company. Whereas Don Smith's preceding article in this issue focuses on the leadership, planning, and management of the handcart emigration, this article focuses on the actual experiences and voices of the emigrants themselves from the time they prepared to leave Europe by sail until they reached Iowa City by rail and anticipated continuing their journey to Zion by foot pulling handcarts.

THE PRIMARY POINT of embarkation for these European converts was, in the mid-1850s, as it had been since 1840, Liverpool. Because of the hazards of pickpockets and others who were ever ready to take advantage of unsuspecting travelers, LDS agents had been stationed at Liverpool for more than a decade. ${ }^{6}$

3. "Foreign Correspondence," Millennial Star 16 (10/28/1854), 684.

4. "Preaching the Gospel, Emigration, \&c," Millennial Star 17 (4/21/1855), 249.

5. Brigham Young was an early advocate of the transcontinental railroad and owned stock in the Union Pacific Railroad. For more on his involvement with the railroad, see Stephen E. Ambrose, Nothing Like It in the World: The Men Who Built the Transcontinental Railroad, 1863-1869 (New York, 2000), 278-96.

6. Soon after LDS emigration was launched from the British Isles, an article titled "Epistle of the Twelve," Millennial Star 1 (April 1841), 311 warned, "We 
These agents proved a blessing to incoming Saints needing help as they commenced their Atlantic voyage. The principal medium of information and communication used was the Millennial Star. On January 12, 1856, for example, the Emigration Department stationed in Liverpool issued the following instructions to prospective Mormon migrants:

Application for passage. - All applications for passage to America must be accompanied by the name, age, occupation, and name of native country, of every individual; and a deposit of $£ 1$ [= about $\$ 5$ U.S.] for each over ONE YEAR OLD, without which no berths can be secured. The time the applicants wish to embark should also be stated, and they will be accommodated as near that date as possible. When a vessel is engaged, we notify such applicants as wish to sail about the time she will be going, by printed circular, giving the date of embarkation, price of passage, and all particulars, to which we require an immediate answer, stating whether the parties notified will embark or not, that in case they are not ready we may have an opportunity to notify others. . . . The prices on the first ship sent out by us under the new Acts were $£ 45 \mathrm{~s}$. [shillings] for adults, $£ 35 \mathrm{~s}$. for children and $10 \mathrm{~s}$. for infants. ${ }^{7}$

Most of the 4,395 passengers from November 30, 1855, to July 6, 1856, were from the British Isles: 2,611 English, 367 Scotch, 667 Welsh, and 54 Irish. There were also 615 from the

have found that there are so many 'pick pockets,' and so many that will take every possible advantage of strangers, in Liverpool, that we have appointed Elder Amos Fielding, as the agent of the church, to superintend the fitting out of the Saints from Liverpool to America. Whatever information the Saints may want about the preparations for a voyage, they are advised to call on Elder Fielding, at Liverpool, as their first movement, when they arrive there as emigrants." At the time that Mormon immigration commenced to Philadelphia, Elder Franklin D. Richards was in charge of the emigration from Liverpool. To ensure lower costs and safety, the foreign converts were encouraged to emigrate in companies. The Millennial Star warned, "To depart from this counsel will bring mischief and destruction to your substance and persons. Hear it Saints and be wise!" "Emigration," Millennial Star 18 (7/5/1856), 427.

7. “Emigration Department," Millennial Star 18 (1/12/1856), 24-25. These prices seem consistent with the cost of maritime travel estimated for the midnineteenth century. By the 1850s, for example, immigrants in general could cross the Atlantic on a decent shipping line from Liverpool to Boston for about \$17-20 in U.S. currency, approximately the same as the Latter-day Saints were paying in British currency. Oscar Handlin, Boston Immigrants, 1790-1880: A Study in Acculturation (Cambridge, MA, 1991), 49. 
Scandinavian Mission, 50 from the Swiss-Italian Mission, as well as two from East India and one from Germany. Of that number, 2,383 are listed as "ordinary" passengers and 2,012 as Perpetual Emigrating Fund (PEF) passengers. ${ }^{8}$

The PEF was launched in 1849 as a revolving loan fund to assist Mormons in the United States who were emigrating to Salt Lake City. In 1853 its focus shifted to helping poor European Saints. The Thirteenth General Epistle issued by Brigham Young and the church's First Presidency in 1856 made the following plea: "Let those who feel an interest in the work of the gathering be liberal in their donations, and prompt in paying what they owe. ... The cry from our poor brethren in foreign countries for deliverance is great." 9

During the peak years of emigration (1852-1887), the PEF assisted about 26,000 immigrants, more than one-third of the total Mormon immigrants from Europe. Throughout the 1850s and 1860s there were three different categories of European immigrants: "The independent, who paid their own way to

8. “Latter-day Saints' Emigration Report," Millennial Star 18 (8/23/1856), 542. Due to the many converts assisted by the PEF in 1856, no LDS immigrants were sent by that means in 1857. "Emigration," Millennial Star 17 (12/27/1856), 820-21, reported, "This Office will not send any P. E. Fund emigrants to Utah, during the year 1857. All the funds that the Company can command will be exhausted in discharging the heavy liabilities, incurred in sending out over two thousand souls, in the year 1856. The Saints will bear in mind that two thousand persons cannot be sent to Utah without incurring an expense of about eighteen thousand pounds sterling."

9. "Thirteenth General Epistle," Millennial Star 18 (1/26/1856), 51; Richard L. Jensen, "The Gathering to Zion," in V. Ben Bloxham et al., Truth Will Prevail: The Rise of the Church of Jesus Christ of Latter-day Saints in the British Isles, 18371987 (Solihull, England, 1987), 176-82. Jensen (180) explains that one unusual aspect of the 1856 emigration was that "Brigham Young and others in the Salt Lake Valley donated valuable property to the PEF, which was sold to British saints of substantial means. The most important such transaction was the sale of President Young's White House in Salt Lake City to Thomas Tennant, a well-todo Yorkshire farmer [for \$25,000]." See also Franklin Richards to "The President of the Perpetual Emigrating Fund Company" [Brigham Young], 3/28/1856, European Mission Letterpress Copybooks, LDS Church Archives, Salt Lake City. The purposes of the Perpetual Emigrating Fund were published in "Emigration," Millennial Star 17 (12/22/1855), 809, which noted that besides the primary objective of reducing costs, there was also the desire "to select mechanics and persons best calculated to build up and strengthen new settlements." Special attention was also paid to "the faithful, long suffering poor" who had been members of the church for the longest period of time. 
Utah; 'states' or 'ordinary' immigrants, who paid only enough to reach a port of entry or other intermediate stopping place in the United States, hoping to earn enough there to finish the journey; and PEF immigrants assisted by the Perpetual Emigrating Fund." Aid recipients were expected to repay their loans after they arrived in the Great Salt Lake Valley. ${ }^{10}$

In 1856 the six voyages that left Liverpool bound for New York and the four voyages launched from Liverpool and disembarking at Boston averaged a 38-day trip. ${ }^{11}$ The largest number of LDS immigrants to cross the Atlantic in 1856 was led by Elder Edward Martin, who had charge of 856 passengers on the Horizon, which disembarked in Boston on June 30. (One of the passengers was British convert Thomas Tennant, who provided the largest PEF donation to assist his fellow Mormon emigrants. $)^{12}$ The second-largest group of LDS converts (764), led by James G. Willie, sailed on the Thornton, arriving in New York on June 14. Both voyages arrived late in the emigration season and as a result suffered greatly while crossing the snowy Plains in the Willie and Martin handcart companies of $1856 .{ }^{13}$ One reason the ships

10. Richard L. Jensen and William G. Hartley, "Immigration and Emigration," in Daniel H. Ludlow, ed., Encyclopedia of Mormonism, 5 vols. (New York, 1992), 2:674. Of the total number of 2,012 PEF passengers in 1856, "333 were ordered out by their friends in Utah, also 788 members, of many years standing in the Church have been forwarded to Utah under the P.E.F. Co.'s arrangements, and 28 Elders returning home from missions." "Latter-day Saints' Emigration Report," Millennial Star 18 (8/23/1856), 542.

11. Deseret News 1997-98 Church Almanac (Salt Lake City, 1996), 161-62. The Emerald Isle, which embarked on November 30, 1855, made the passage in the shortest time, landing in New York in 30 days; the John J. Boyd, which left Liverpool on December 12, 1855, did not arrive in New York until February 15, 1856 , after a 65 -day voyage.

12. Tennant was the major source of financial support for the PEF in 1856. Franklin Richards to "The President of the Perpetual Emigrating Fund Company [Brigham Young]," 3/28/1856, European Mission Letterpress Copybooks, LDS Church Archives; Jensen, "Gathering to Zion," 180.

13. Some historians blame this tragedy on Franklin D. Richards, who presided over emigration affairs from Liverpool. However, LeRoy R. Hafen and Ann W. Hafen, Handcarts to Zion: The Story of a Unique Western Migration, 1856-1860 (Glendale, CA, 1960), 47-48, point out that "throughout January and February [1856] President Richards had continually urged the necessity of getting off early. The winter's severity, with hard times and high prices, sharpened the Saints' desire to emigrate. Many of these, carried away with the idea of gathering to Zion that season, left their various employments even before arrange- 
were delayed was bad weather, which made it difficult for vessels to come to port in Liverpool.14 Ship availability was also hampered by the Crimean War, which lasted until the end of March 1856.15

THE FIRST VESSEL carrying Mormons who eventually outfitted at Iowa City was the John J. Boyd, which left Liverpool in December 1855, arriving in New York on February 15, 1856. ${ }^{16}$ That unpleasant voyage demonstrates the effect the commanding mariner wielded on a sailing ship. Thomas Austin, the master of the John J. Boyd, resented the presence of the Latter-day Saints aboard his ship. Adding to his frustration, the vessel encountered strong headwinds, a tornado, two fires, and a collision with another ship, resulting in a lengthy 65-day voyage-nearly four weeks longer than the average trip across the Atlantic for vessels

ments had been made for their transportation. The result was that some of them were left to choose between the alternatives of remaining in Great Britain during the winter to starve or go to the poor house, or else run the risk of a late journey across the plains. They chose the latter course, in which the presidency of the British Mission, seeing no better way out of the difficulty, acquiesced, and chartered the ships, 'Horizon' and 'Thornton.' Procuring the boats depended greatly upon winds and weather, and upon conditions of commerce." Furthermore, in a letter to Brigham Young, 3/28/1856, Richards noted that 20 men, not just Richards, were involved with the decision to plan for the circular "Emigration to Utah for 1856." See Millennial Star 18 (2/23/1856), 121-23.

14. See, for example, James Linforth to President Franklin D. Richards, 2/22/ 1856, European Mission Letterpress Copybooks, 1851-1889, LDS Church Archives; and "Emigration," Millennial Star 18 (4/5/1856), 218. The latter article also notes, "The scarcity of ships for the more northern of the American ports has caused a considerable rise in the price of passage."

15. Thanks to Mormon historian Don H. Smith for bringing this point to my attention as well as the idea that the availability of vessels was scarce because of the poor weather. William C. Dunbar, an agent authorized to assist emigration business, wrote, "Ships are very scarce, indeed, on account of a great number being enlarged in the War Department." I copied this statement by Dunbar from a display at the "Sun Ranch," which is operated by The Church of Jesus Christ of Latter-day Saints at what is commonly known as Martin's Cove, the primary area where the Martin handcart company suffered greatly.

16. Andrew Jenson, "Detailed Emigration Account, 1855," The Contributor 13 (October 1892), 553-54, notes that the bulk of these immigrants went to either St. Louis, Missouri; Alton, Illinois; or Burlington, Iowa, to seek employment for at least a year before continuing their journey to the Salt Lake Valley. 
carrying Mormons in 1856. ${ }^{17}$ According to Mormon passenger Peter Gottfredson, Captain Austin told LDS voyage leader Knud Petersen, "If I hadn't damned Mormons on board I would have been in New York six weeks ago." The bold Dane promptly replied, "If you hadn't Mormons on board, you would have been in hell six weeks ago." 18 One equally fearless Mormon passenger, Patience Loader, reported that when the captain informed the Saints that "if we did not stop our D--- preaching and praying we would never land in New York," she responded to one of the mates, "That was the only thing that saved his vessel," for, she said, "he was such a wicked drinking man and neglected his duty." Loader further noted that one night the captain's state of intoxication had caused the ship to catch fire. ${ }^{19}$

In stark contrast, LDS voyage leader Dan Jones, a mariner himself, had a positive experience on another ship carrying Mormons that year, the Samuel Curling. Regarding the vessel's owner and master, Captain Curling, Jones reported his kind, chivalrous behavior, and commented on their personal relationship: "We have spun yarns together for hours, as we paced the deck eagerly scrutinizing the horizon. ... With such a one, hours have I spent with a pleasure known only to weather beaten old tars. May he moor his barque, yes, his fleet in Zion's snug harbor, ere the equinoctial gales of life beset him." 20

Another commendable example of a Mormon maritime migration across the Atlantic in spite of severe seasickness was the voyage of the Enoch Train. Mormon ship leader James Ferguson wrote back to Liverpool that soon after they embarked "a great many were very sick." Yet at the end of the voyage, with more than 500 Saints on board, Ferguson noted, "We have no grum-

17. For more on this infamous voyage, see the Mormon Immigration Index CDROM under John J. Boyd, "Personal Accounts." This CD-ROM, compiled and edited by Fred E. Woods and published by The Church of Jesus Christ of Latter-day Saints in 2000, is available at LDS church distribution centers in Utah.

18. Conway Sonne, Ships, Saints and Mariners (Salt Lake City, 1987), 120; Peter Gottfredson, Autobiography, 8-9, LDS Church Archives. Gottfredson was 9 years old while on board the John J. Boyd.

19. Patience Loader Rosa Archer, Reminiscences, 45, LDS Church Archives.

20. Dan Jones (in Boston aboard the S. Curling) to President Franklin D. Richards, 5/21/1856, in Millennial Star 18 (7/5/1856), 429. 
blers, and no murmurers, everybody is contented and happy." Mormon immigrant Andrew Smith recalled, "We had plenty of rolling about, upsetting of dishes \&c in the galley and being difficult to stand. Sometimes some were sent sprawling across the deck or thrown down ... . and only turned out to merriment on the part of the Saints." Smith added, "All kinds of games were resorted to [to] keep us in lively exercise during the day. The band frequently playing and the brethren \& sisters collecting together, singing or dancing, made the time pass away agreeable, so that those who were sick got on deck as soon as they could to join in the sport." Fellow LDS passenger Archer Walters remembered that when the band played, all were "as merry as crickets." He also recorded that along with dancing, others were "busy on deck making and sewing tents." In a letter to Elder Richards, Ferguson detailed the good spirits of those on the Enoch Train: "The unity, cleanliness, and devotion of the whole company, from Liverpool to Boston, would not present a single spot for criticism. . . . American, English and Scotch, seemed ... like ministering angels sent to whisper peace and comfort to all hearts. There was not a jar, but all delighted to bless and do good to each other." 21

The Saints were impressed with the kind and gentlemanly conduct of Captain H. S. Rich, master of the Enoch Train. At the conclusion of the Atlantic crossing, Ferguson and Rich exchanged letters of commendation. The captain received a letter expressing gratitude for his benevolence, and Rich's letter to Ferguson and the other elders thanked them "for the spirit of kindness manifested by you and all during the present voyage, tending to the health and comfort of our passengers under your charge. If such rules and regulations could be followed by all emigrant ships, we should have less, far less of sickness and distress at sea. Cleanliness is part of your religion, and nobly you have carried it out." 22

21. Andrew Smith, Journal, 3/24/1856, LDS Church Archives; "Emigration Department," Millennial Star 18 (1/12/1856), 26; James Ferguson to Franklin D. Richards, 5/11/1856, in "Foreign Correspondence," Millennial Star 18 (6/28/ 1856), 414.

22. James Ferguson to President Franklin D. Richards, 4/30/1856, in "Report from the Enoch Train," Millennial Star 18 (6/7/1856), 355. 
At the time of disembarkation, the captain introduced Ferguson to the owners of the vessel and the shipping firm known as the House of Train and Company. Ferguson observed, "Their attentions gave us a high position in the estimation of the people of Boston," countering the misconceptions that circulated regarding the LDS faithful. Andrew Smith recalled, "Many of the [Boston] natives flocked to the ship to have a peek at the Mormons and their wives." He further noted, "The people of Boston entertained peculiar notions respecting us as a people and it is thought our visit there will have a good effect in removing a little prejudice from the minds of some. It was acknowledged that a more respectable class of emigrants had not made their appearance in Boston." In addition, Ferguson noted that when the quarantine doctor and government agent came on board to inspect the passengers, they pronounced the company "as far ahead of anything they had ever seen. They were followed by a number of members of the Massachusetts Legislature, who were all astonished at our cleanly, healthy appearance, and ... declared their delight at seeing such a class of people come to settle in their country." 23

BY THE SPRING OF 1855, the port in New York had become the entry of choice. There, in the same year, the earliest American immigration depot, known as Castle Garden, was erected. When Charlotte Ann Hilstead, a 12-year-old LDS traveler landed at the depository, she remarked, "We landed on what they called Castle Garden, but I did not see a castle nor a garden. It was just a big wooden shed with a roof across it." Although not remotely resembling a castle, the fortified structure helped to protect immigrants from thieves and others looking to take advantage of them. Dr. George J. Svejda noted that at Castle Garden, "the first official receiving center for immigrants in the country, so severe a blow was struck against the business of swindlers that it aroused resentment and opposition from the 'runners,' who saw in it an interference with their private vested interests." Although this structure afforded improved external protection for

23. Andrew Smith, Journal, 4/30/1856; James Ferguson to Franklin D. Richards, 5/11/1856, in “Foreign Correspondence," Millennial Star 18 (6/28/1856), 414. 
immigrants in general, the LDS agents, the valiant "knights near Castle Garden," provided even greater security and assistance for the incoming Saints. They aided vulnerable foreign converts in making the transition into a new country. Providing directions through the crowded city of New York, and at times even offering economic assistance, these agents helped many emigrants continue their journey west to LDS outfitting posts and eventually on to Salt Lake City. ${ }^{24}$

Elder John Taylor (an LDS Church Apostle) had an office in New York from 1855 to 1857, from which he supervised the affairs of the Latter-day Saints Eastern States Mission. His responsibilities for eastern congregations and missionaries included assisting incoming LDS immigrants. Brigham Young, who had an aptitude for detail, counseled Mormon Apostle and Liverpool emigration agent Franklin D. Richards to keep Taylor informed:

Whenever you ship a company, whether it be small or large, be careful to forward to Elder John Taylor, at New York City, a correct list of the names of the persons in each company, with their occupation, and appropriate amount of property or means, and forward it in season for Elder John Taylor to receive it before the company arrive in port, that he may be so advised as to be able to meet them, or appoint some proper person to do so, and counsel them immediately on landing as to the best course for each and all in every company to pursue - viz., whether to tarry for a season to work in the place or immediate neighborhood of their land, or proceed to Cincinnati and its region, \&c. ${ }^{25}$

24. The Life of Charlotte Ann [Hillstead] Bates, 3, LDS Church Archives; George J. Svejda, Castle Garden as an Immigrant Depot, 1855-1890 (Washington, DC, 1968), 44-45. For the history of Castle Garden in the Mormon context, see Don H. Smith, "Castle Garden, the Emigrant Receiving Station in New York Harbor," Nauvoo Journal 10 (1998), 41-52. For more on the Mormon agents at New York, see Fred E. Woods, "The Knights at Castle Garden: Latter-day Saint Immigration Agents at New York," in Alexander Baugh and Andrew H. Hedges, eds., Regional Studies in Latter-day Saint Church History: New YorkPennsylvania (Provo, UT, 2002), 103-24. “Emigration," Millennial Star 18 (4/5/ 1856), 218, counseled elders (Latter-day Saint missionaries) returning home from their missions to assist LDS immigrants in "the disposition of their effects" prior to their departure. "The Gathering of the Poor," Millennial Star 18 $(2 / 2 / 1856), 73-74$, instructed the missionaries to watch over their poor converts as they gathered to Utah.

25. Millennial Star 16 (10/28/1854), 684. 
Taylor used a local New York LDS newspaper, The Mormon, of which he was editor, to assist emigrants with temporary jobs and other needs. Its first issue, dated February 17, 1855, gave notice that a major object of the paper was to advise emigrants regarding routes and other pertinent instructions. The newspaper included dates of port arrivals as well as employment opportunities for those who needed to secure funds in order to continue their journey west. Two weeks after The Mormon was established, it informed local missionaries that, "as there will shortly be many of our brethren here from Europe who will be in want of employment, in various trades and occupations, you are requested to send to this office, directions whereby we may know where to send those that are in need of employment, on their arrival to this country." 26

A few months later, The Mormon emphasized the distribution of emigration information as one of its primary goals:

We shall endeavor to be always prepared to impart the latest information relative to the best course to be pursued by Emigrants on their arrival in Boston, New York and Philadelphia. Our emigrants have heretofore, almost exclusively gone by the way of New Orleans, but will hereafter land in the Eastern cities, and one of the principal objects of establishing "The Mormon" is for their information, as well as other emigrants arriving in this country.

We shall take special interest in seeking out the cheapest, best and most convenient mode of conveyance from this and other points, as well as to observe the course pursued by agents in the accommodation for travelers on the routes and make of "The Mormon" a directory, to which all Emigrants and Travelers may refer with some degree of safety.

And we have traveled over the road several times and know from experience the wants of those seeking a home in the West. We have sought with diligence, at the several points for outfitting, the various and best kind of establishments, and as the spring opens shall fill all our business columns with advertisements, for the conveyance and direction of Emigration in making their purchases, \&c. ${ }^{27}$

Although this means of providing up-to-date information proved effective, just two years later the newspaper was discon-

26. The Mormon, 2/17/1855, 3/3/1855.

27. "To the Emigration and our Readers Generally," The Mormon, 6/2/1855. 
tinued when Taylor and other elders were called home to the Salt Lake Valley because of the Utah War. ${ }^{28}$

As long as Taylor was stationed at New York, however, he kept an observant eye on immigrants entering not only New York but other eastern ports as well, and through careful negotiation he tried to arrange the best possible rail travel for them. In the early spring of 1856, for example, he wrote to Brigham Young:

A ship load of passengers is expected here shortly. They come by way of Boston. I have been enabled to make better arrangements for their conveyance to Iowa City by the New York R.R. than by the Boston line; they will therefore come to New York. This may bring the Bostonians to terms another time. I have managed to keep up opposition between the railway companies thus far and wish to continue it. The New York \& Erie R.R. Co. bring our emigrants from Boston and thence to Iowa city for 50 cents less per head than the Boston company will take them direct. ${ }^{29}$

Thus, during the 1856 Mormon emigration season, European converts were routed from Boston through New York and then carried by rail to Iowa City, the terminus, as of December 31, 1855, of the Chicago and Rock Island Railroad.

Meanwhile, those migrants who arrived in Boston found their way eased by LDS agent Daniel Spencer, who was charged

28. For a biographical sketch of John Taylor, who later became the third president of The Church of Jesus Christ of Latter-day Saints, see Andrew Jenson, comp., Latter-day Saint Biographical Encyclopedia, 4 vols. (Salt Lake City, 19011936), 1:14-19. After Taylor left for Salt Lake City, Thomas B. H. Stenhouse, who had been assisting Taylor with The Mormon, remained in New York to assist emigrants. James Dunn, an LDS immigrant in 1857, noted, “As soon as I landed in New York I went to report myself to Apostle John Taylor whose address I had but when I found his office he had gone to Utah and T. B. H. Stenhouse was in charge." Stenhouse turned Dunn over to a Brother Simonds, who helped him find employment. See James Dunn, Autobiography, 12, LDS Church Archives.

29. John Taylor (New York) to Brigham Young (Salt Lake City), 4/16/1856, incoming correspondence to Brigham Young, LDS Church Archives. See also John Taylor (New York) to Brigham Young (Salt Lake City), 5/17/1856, ibid. Nathaniel H. Felt, who assisted with emigration on the East Coast and earlier in St. Louis, was mentioned in the latter and in a letter by Dan Jones, who remembered Felt's "judicious counsels." Dan Jones (Boston) to President Franklin D. Richards, 5/21/1856, Millennial Star 18 (7/5/1856), 430. For more on Felt, see Fred E. Woods, "Nathaniel H. Felt: An Essex County Man," in Donald Q. Cannon, Arnold K. Garr, and Bruce A. Van Orden, eds., Regional Studies in Latter-Day Saint Church History: The New England States (Provo, UT, 2004), 219-36. 


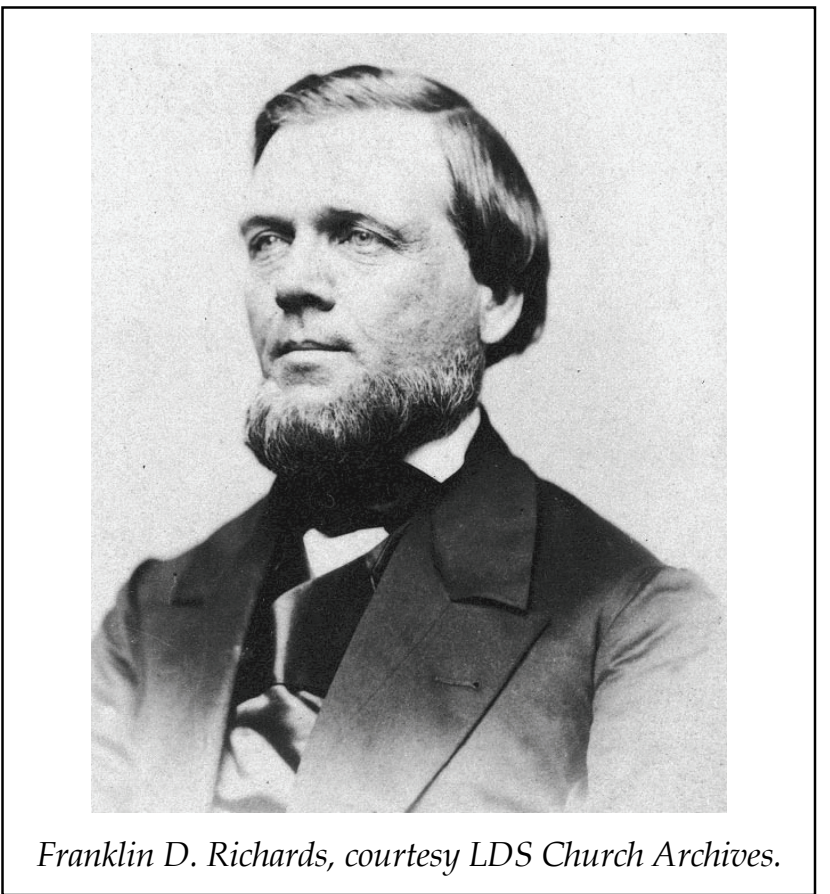

with overseeing LDS emigrants in 1856. Spencer had worked with Franklin D. Richards in Liverpool, until Richards authorized Spencer "to contract \& use his name in all matters" pertaining to emigration business for the Saints. Soon thereafter, Spencer and Chauncey G. Webb and two other elders, John Van Cott and John Goodsall, left Liverpool for Boston. They disembarked at Boston on March 30, 1856. The following day, Spencer "called upon 'Enoch Train' \&c. . . . was kindly entertained by Mr. Twain [Train] and all interested with him." On that same day, Spencer "called upon Mr. Twichel, president of the Boston \& Massachusetts Limited Railroad Company. Mr. Armstrong accompanied me by request of Mr. Twain [Train]." Van Cott and Spencer spent the next two days "making inquiries as to the prospect of forwarding our passengers on the railroad west" and negotiating the price of passage to Iowa City. ${ }^{30}$ 
Just one month later, more than 500 Saints disembarked from the Enoch Train at Boston and reaped the fruit of Spencer's labor and collaboration with Train \& Company. Soon after arriving in Boston, the emigrants were forwarded to Iowa City via New York at the price of $\$ 11.50$ for those 14 or older, $\$ 5.75$ for youth ages 4 to 14 , while those under 4 went free of charge. ${ }^{31}$

For those who continued to use Boston or New York as an arrival port in 1857, the rate to sail the Atlantic remained about the same as in 1856. Beyond sheer monetary expenditures, the costs of the journey included health risks and severed family and social ties. Job Pingree recollected that some of his company "died crossing the sea." In most cases, migrants were permanently separated from their loved ones. Mary Seamons Thurston recalled, "We all felt sorrowful at leaving our dear homes and friends, although many had turned against us because we were 'Mormons.' " 32

In 1857 three chartered Mormon voyages disembarked at Philadelphia, one in Boston, and only a few individual Mormon families sailed to New York City. ${ }^{33}$ The combined total of mi-

praised Spencer for his work in the British Isles. Spencer also served as president of the Salt Lake City Stake from 1849 until his death in 1868. For more on Spencer's life, see Latter-day Saint Biographical Encyclopedia, 1:286-89.

31. Millennial Star 18 (6/14/1856), 377-78, notes, "It has been found advantageous, this season, to send most of the passengers per P.E. Fund, via Boston, as those who pass directly through, without settling in the State of Massachusetts, are not charged the usual eight shillings and four pence for head money, which is required to be paid for all persons who stop to reside in that state.... The proprietors in Boston have extended to our Agent, Elder D. Spencer, every advantage to facilitate our forwarding business on that side, which could be reasonably expected." Andrew Jenson, "Ninety-Third Company," The Contributor 14 (November 1892), 19-20, also notes, "Owing to the competition between railway companies, the price for adult passengers from Boston to Iowa City was subsequently reduced to ten dollars, and children in proportion."

32. Job Pingree, Life History, 1, LDS Church Archives; Mary Seamons Thurston, Autobiography, 2, LDS Church Archives.

33. As a result of the ill-fated Willie and Martin handcart companies, which had suffered while crossing the Plains, largely due to a late departure coupled with other factors, Mormon authorities insisted that "all Saints who intend going to Utah in 1857, must make their calculations to sail from this port, by the 25th of March, so as to land in the States by the 1st of May." "Emigration," Millennial Star 18 (10/11/1856), 651. However, of the four chartered voyages that year, only the George Washington disembarked before May 1, arriving in 
grants for the year reached nearly 2,000.34 The selection of Philadelphia was probably based on a cheaper travel fare-a factor that often determined the route, whether by sail or rail - and the location of the trail outfitting post for each emigration season. 35

Of course, the decision to disembark at Philadelphia affected the route and cost of rail travel to Iowa City. In the absence of New York LDS agent John Taylor, agent Angus M. Cannon met the first load of Mormon immigrants to disembark at Philadelphia. Voyage leader Matthias Cowley noted that "arrangements were made for us to proceed on our journey ... per train to Iowa City, costing $\$ 10.50$ per each adult, half price for all under fourteen and over six year of age; all under six years old nothing." Before their train departed, \$5,572.04 was collected from the passengers to pay their rail fare from Philadelphia to Iowa City. Caroline Hansen Adams wrote that just one day after arriving in Philadelphia, the group "boarded a train and traveled west to Iowa City," arriving there eight days later on June 9. Johan F. F. Dorius concurred, noting, "We traveled eight days and nights, a distance of about 1500 miles to Iowa City. We passed through many towns and places, and it was

Boston on April 20, 1857. See Deseret News 1997-98 Church Almanac, 162, for the departure and arrival dates for these chartered voyages.

34. According to the Deseret News 1997-98 Church Almanac, 162, 1,127 Saints disembarked at Philadelphia in 1857, 544 from the Westmoreland, 547 from the Tuscaora, and only 36 from the Wyoming. The Boston port received 817 passengers, who crossed the Atlantic on the George Washington, bringing the combined total of LDS chartered passengers to 1,944 for the year. This does not include a few LDS passengers who deported at New York on two different voyages, neither of which were chartered. Philadelphia was not used by the Saints as a port again until 1886, and then for only one vessel due to unusual circumstances. With the opening of the Castle Garden immigration depot, New York became the primary port of disembarkation for the Saints until its demise by fire in the late 1880s. Between 1855 and 1890, more than 65,000 out of about 90,000 total Latter-day Saint migrants passed through Castle Garden, which saw about eight million immigrants pass through its doors.

35. Philadelphia began to be used as a port of immigration for the Saints in 1855 as a result of Brigham Young's counsel to LDS Liverpool agent Franklin D. Richards. In 1855 four Mormon voyages disembarked at Philadelphia, though none did in 1856, possibly because of the cost as well as the opening of Castle Garden in New York in 1855. For more on Mormon migration through Philadelphia, see Fred E. Woods, "'Pronounced Clean, Comfortable, and Good Look': The Passage of Mormon Immigrants through the Port of Philadelphia," Mormon Historical Studies 6 (2005), 5-34. 
enjoyable to ride through this beautiful country, which exhibited fertility and blessings, conveying the idea to us that it was a land blessed of the Lord." 36

Not all of the immigrants were able to head west immediately, however. Incoming European Saints faced religious prejudice, and, for some, the challenge of securing enough money to continue their journey to Utah. A number of Mormon migrants remained in the eastern states, stranded by a lack of funds. In 1856 the Millennial Star reported that soon after LDS passengers had arrived in New York aboard the Caravan, they were compelled to seek temporary employment in the region. James and Rachel Hancey, for example, remained in New Jersey for several years to work. Upon disembarking at New York, William and Ann Richardson soon left for Pittston, Pennsylvania, and did not reach their Utah destination until seven years later. ${ }^{37}$ Although both the Hancey and Richardson families were originally bound for the Mormon outfitting post in Iowa City, by the time they secured the necessary funds to continue their trek, the outfitting post had been changed to Florence, Nebraska, with the railroad's westward advance.

Financial assistance from fellow Saints helped many other Mormon immigrants continue on to Iowa City. Joseph Orton, also a Caravan passenger, recalled, "Almost penniless reaching New York, I remember with deep gratitude the kindness of my brethren and sisters, especial of Brother Joseph Oxborrow and wife, who tho' lately emigrated, assisted so many temporally." Although appreciated, such assistance was often not enough. Therefore, upon arrival at New York, Orton secured temporary employment by hiring out to a farmer who resided on Staten Island. Not accustomed to such labor, Orton moved on to New York City, where he was able to pursue his craft as a shoe-

36. "Report of the 'Westmoreland," Millennial Star 19 (7/11/1857), 445-46; Public Ledger, 6/2/1857; Autobiography of Carline Hansen Adams, in Kate B. Carter, ed., Our Pioneer Heritage, 20 vols. (Salt Lake City), 12:472; Johan F. F. Dorius, Journal, 6/2/1857, in Church Emigration Book (1855-1861), LDS Church Archives.

37. Andrew Jenson, "Ninety-Second Company," The Contributor 14 (November 1892), 18-19; Rachel Seamons Hancey, Autobiography, 6, in Collected information on the Seamons and related families, LDS Church Archives; William Richardson, Journal, 19-21, 36, LDS Church Archives. 
maker. He did not realize his goal to see the city of the Saints until two years later. 38

FOR THOSE SAINTS who were able to continue on, the next transportation hurdle was rail travel. The rail route for many began in Albany, New York. Samuel Rowley recalled, "After landing at Castle Garden [New York] we sailed up the Hudson River to the terminal of the Rock Island Railroad." 39 Those who disembarked from the port of Boston also traveled through Albany before going west by rail. Thomas Durham's journal provides useful travel details: "We took the cars at Boston for Iowa City on the 2nd of July [1856] and got there on the 8th, the distance of 1700 miles. . . . We passed through Albany, Buffalo, Cleveland, Toledo, Chicago, Rock Island, \&c." 40

It was not a pleasant experience. Andrew Smith recalled, "It was very rough traveling upon the railways in this country. It is nothing strange to be knocked out of your seat and frequently to pass heaps of cars and engines all smashed up by collision or otherwise. ... The road from Devon Point [Davenport] to Iowa City is awful ... the rails laid quite crooked." Elizabeth White Steward remembered the rail ride from Boston to Iowa City as "a very unpleasant journey. We were put in cars that had no seats and we had to sit on our trunks and baggage with no room to lie down at night." George Harrison echoed her sentiments,

38. Joseph Orton, Autobiography, 8-11, LDS Church Archives.

39. A Biographical Sketch of the Life of Samuel Rowley, 1, LDS Church Archives. Mormon emigrants took various rail routes from Boston and New York to Chicago, where they transferred to the Chicago \& Rock Island Railroad and made their way to Rock Island, Illinois. After crossing the Mississippi River, they then took the Mississippi \& Missouri Railroad (a branch of the Chicago \& Rock Island) from Davenport, Iowa, to Iowa City. See F. Daniel Larkin, "Chicago \& Rock Island Railroad," in Robert L. Frey, ed., Encyclopedia of America Business History and Biography: Railroads in the Nineteenth Century (New York, 1988), 45-46; Alex Kirby, "Thomas C. Durrant," ibid., 112.

40. Thomas Durham, Journal, 14, L. Tom Perry Special Collections, Harold B. Lee Library, Brigham Young University, Salt Lake City. For other accounts detailing rail travel routes from the East Coast to Iowa City, see William Lawrence Hutchings, Diary, 4/23-30/1856, LDS Church Archives; Josiah Rogerson, Autobiography, LDS Church Archives; Benjamin Platt, Autobiography, 2, LDS Church Archives; John Kettle, Journal, in The Protecting Warrior, Book 1 (Murray, UT, 1972), 56; James Palmer, Reminiscences, 172, LDS Church Archives. 
noting, "the cars were so crude and the railroad so rough we were all tired out when we arrived in Iowa City." Peter Howard McBride explained, "From Chicago, we had to ride in cattle cars and freight cars." 41

Rail travel was not only uncomfortable, it could also be dangerous. On May 6, 1856, Mary Powell Sabin remembered, “Our train was scheduled to cross the Mississippi River on a bridge at eight o'clock. We were fifteen minutes late. The bridge broke with the train just ahead of us and a great wreck occurred." The accident delayed Sabin and her traveling companions for two days. Although temporarily delayed, one fellow passenger speculated that their tardiness in meeting the train schedule meant that the lives of the rail passengers had been spared "from plunging into the Mississippi River." 42

Because of the damage to the bridge, none of the Mormons who emigrated during that summer season could use the rail bridge, which did not reopen until September 8,1856 . In the interim, emigrants had to take a ferry across the Mississippi River. Peter Madsen, Joseph Beecroft, and Heber Robert McBride all recalled crossing the Mississippi that summer on steamboats due to the damage to the bridge from the Effie Afton incident. ${ }^{43}$

41. Andrew Smith, Journal, 5/12/1856; Elizabeth White Steward, Autobiography, in Ruth Johnson and Glen F. Harding, eds., Barnard White Family Book (privately printed, 1967), 187, LDS Church Archives; George Harrison, Autobiography, in Kate B. Carter, comp., Treasures of Pioneer History, 20 vols. (Salt Lake City, 1958-1977), 2:106-7; Peter Howard McBride, Journal, in Carter, Our Pioneer Heritage, 13:360. Priscilla Merriman Evans, Autobiography, 39, LDS Church Archives, notes that the company of Saints Evans journeyed with to Iowa City by rail also traveled in cattle cars.

42. Mary Powell Sabin, Autobiography, 8, LDS Church Archives; Emma McDowell Jacobson, Our Powell/Peterson Ancestors, 18, LDS Church Archives. The wreck Sabin narrowly missed was a famous one. On May 6, 1856, just two weeks after the Rock Island bridge had opened to great fanfare, a steamboat, the Effie Afton, struck one of the bridge's piers and caught fire, destroying the boat and a portion of the bridge. When the steamboat company sued, challenging the railroad interests, Abraham Lincoln successfully defended the bridge company. See Benedict C. Zobrist, "Steamboat Men Versus Railroad Men: The First Bridging of the Mississippi River," Missouri Historical Review 59 (1965), 165-68; John C. Parish, “The First Mississippi Bridge," Palimpsest 3 (1922), 137; and "Lincoln and the Bridge Case," ibid., 142-54.

43. Peter Madsen, Diary, 6/26/1856, LDS Church Archives; Joseph Beecroft, Journal, 7/8/1856, ibid.; Heber Robert McBride, Autobiography, L. Tom Perry Special Collections, Harold B. Lee Library, Brigham Young University. 
For some, the delay appears to have had been a mixed blessing. During some warm June weather, William Woodward recalled that the Saints in his company took advantage of the situation, as "many of our company bathed in the Mississippi River." Yet Woodward also points out that during this period of detainment, "two Irishmen made a difficulty, because we were not willing to let them pass through the cars. One of the Irishmen tore a piece from the shoulder of my coat. Captain [Dan] Jones kicked one of them because he would stand on the car. The cars were guarded by many of our men during the night." 44

AS MORMON EMIGRANTS TRAVELED by rail from the East Coast, a number of newspapers in cities along the route reported on their westward migration. It was by then well known (thanks to the press) that the Mormons in Salt Lake City were practicing polygamy. ${ }^{45}$ The press on both sides of the Mississippi River in Rock Island, Illinois, and Davenport, Iowa, generally reported a one-sided, negative view of the Mormon migrants as they traveled west by rail towards Iowa City in 1856 and 1857. As the editor of the Rock Island Morning Argus put it, "Some three hundred mormons arrived last night, by the Chicago and Rock Island railroad and departed this morning for the valley of abominations at Salt Lake." When some Mormons arrived at the Davenport depot, Patience Loader recalled, "A great crowd gathered around us casting slurs at us and asking father if he was going to take his fine girls to Utah and give them to Brigham Young for wives. They said that old fellow already got plenty of wives." Loader added, "This was the roughest place we came to in our journey from New York." One female Mormon emigrant facetiously told an Iowa City reporter that she had several husbands. The gullible reporter not only included in his article that the woman had "no less than four husbands," but added, "she is said to have been an intelligent individual." 46

44. William Woodward, Diary, 6/1/1856, LDS Church Archives.

45. See, for example, articles denouncing the Mormon practice of polygamy in the Davenport Daily Gazette, 6/6/1856, 6/10/1856, and 4/15/1857.

46. Rock Island Morning Argus, 5/1/1857; Patience Loader Rosa Archer, Reminiscences, 55; Iowa City Daily Evening Reporter, 8/16/1856. See also Rock Island Morning Argus, 5/12/1856 and 4/30/1857. 
Despite being generally jaundiced, newspaper reports offer details that help us piece together a view of the Mormon migrants who traveled by rail across Iowa in June 1856:

Another large batch of Mormons passed through our city yesterday morning. They numbered between four and five hundred and comprised men, women and children,-some of the women carrying babes in their arms. One man was limping along on a wooden leg, and we noticed two or three old men and women who seemed fitter for tottering over the grave, than for taking the weary pilgrimage to Utah. We understand that those who passed through yesterday are about half a company which recently came from England, and about two-thirds of them were of the lowest class of Welsh, the remainder being English and Scotch. ... We doubt not that the authorities of England look upon their departure as a happy riddance.

Ten days later, the same Davenport paper reported: "Seven cars loaded of Mormons reached the city today and passed on up to camp - a hard looking set, sweltering in black clothes beneath a sultry sun, and moving on westward like so many mourners for the loss of common sense." A subsequent editorial noted, "Another detachment of Mormons passed through our city yesterday morning. They numbered several hundreds, and were about as miserable looking as those who have preceded them." The following month, the same newspaper continued to slander the Mormon emigrants: "Eight hundred more of the deluded followers of Mormonism passed through our city yesterday.... This company is about on par with its predecessors and is composed of a class of persons more illiterate, than it seems to us could be scraped together in any portion of this country." 47

The press in Iowa City also took note of Mormon migration during the spring and summer of 1856. The Iowa City Republican ran several articles in the same issue regarding the Saints' movement. One reported, "Quite a number of Mormons started last week from their camp two miles west of this city, on their way to serve as 'working bees' in the hive of Deseret." That article and others suggest that reporters viewed the migrants as naïve victims of LDS church leaders. 48

47. Davenport Daily Gazette, 6/3/1856, 6/13/1856, 6/27/1856, and 7/9/1856.

48. Iowa City Republican, 6/23/1856. The fact that the Republican Party had launched its 1856 campaign against the "twin relics of barbarism" - slavery 
THROUGHOUT THE YEARS 1856 and 1857, regardless of the port of entry or the rail route the Saints used, the farthest railhead west terminated in Iowa City. During the years of Mormon migration through the area, the town flourishedthanks mainly to the railroad. Between 1854 and 1856-the railroad arrived December 31, 1855-the population of Iowa City had more than doubled (from 2,570 to 6,316). ${ }^{49}$

Upon reaching Iowa City, Mormon migrants were met by LDS agent Daniel Spencer in 1856 and agent James A. Little in 1857. In early May 1856, Spencer, the Mormon agent assigned to oversee the westward migration through Iowa City for the year, had selected a fine location for an emigrant campground "on a rising point of land" about two miles west of town. When William Woodward arrived in Iowa City on June 2, 1856, he found "several of the brethren ... at the railroad depot waiting our arrival. . . . I drove a team from the depot to the camp of the Saints, about two miles west of Iowa City. ... I received a kind welcome from Daniel Spencer. ... A good feeling existed in the hearts of the Saints that were in camp previous to our arrival. Our company swelled the number of the camp to about $1400 . " 50$

Mary B. [Brannigan] Crandell arrived on June 1, 1856: "Oh what a sight met my gaze! Tents pitched, men working at the handcarts, women cooking outdoors, every person busy as a bee. I thought I had got into the hive of Deseret sure. . . . Everyone was so kind to me when they found I was alone that I soon dried my tears and went around the camp to see what was going on, everything was so new and strange." While viewing the beautiful countryside with her head out the train window, Crandell had lost her bonnet, but "one of the brethren came to the rescue. He had two hats, and lent me one, so I came to the camp with a man's hat on; blushing like a red rose, for I had been told that if I put a gentleman's hat on, he had the right to

and polygamy - helps explain why newspapers in Iowa City and on both sides of the Mississippi River would report unfavorably about Mormons passing through. Davenport Daily Gazette, 2/1/1856.

49. Johnson County 1854 census, Johnson County IAGenWeb site, http:// iagenweb.org/census/johnson/1854/IA-1854-IowaCity.txt; Johnson County 1856 census, State Historical Society of Iowa.

50. William Woodward (Iowa City) to Heber C. Kimball, 6/11/1856, LDS Church Archives; William Woodward, Diary, 6/2/1856. 
kiss me and I did not know what I would do under such circumstances, perhaps tell him to put it back where he got it." 51

The following year, another Mormon emigrant recalled the Saints' kind assistance upon her arrival at the Iowa City rail depot. She noted that teams awaiting her company's arrival transported the emigrants to the campground, where a stream of water ran through a grove of trees. "I had no money left," she recalled, "so we went to the captain of the camp, James A. Little, and told him of our plight. He furnished us with something to eat. ... He also gave permission to get work in Iowa while preparations were being made for the trip across the plains." 52

Little, who had arrived from St. Louis the night before, was just in time to receive those who had crossed the ocean on the George Washington. In St. Louis Little had gathered tents, wagon covers, and provisions to prepare for the incoming Saints, and upon their arrival, he quickly oversaw the erection of tents and wagon covers for temporary bedding. 53

51. Mary B. Crandell, “Autobiography of a Noble Woman," Young Woman's Journal 6 (April 1895), 318-19.

52. Susan Melverton R. Witbeck, Autobiography, 4, LDS Church Archives. It appears that not everyone had the privilege of wagon transportation to the camp. When the emigrants arrived, the size of their companies affected the availability of transportation to the Mormon campground. Archer Walters, who arrived a few weeks before Woodward, noted on his arrival on May 12, 1856: "Dragged our luggage about 2 miles to camp ground." Archer Walters, Diary, 5/12/1856.

53. J. A. Little to Orson Pratt, 4/26/1857, in "Foreign Correspondence," Millennial Star 19 (6/13/1857), 377-79. Little was involved in other emigration business matters as well, including corresponding with a wagon maker in Chicago "who is making our wagons." Ibid., 377. Charles Root Dana, Autobiography, 5/30/1857, LDS Church Archives, notes, "By Elder Little's request, I went to Chicago to pay a debt of one thousand dollars which he owed for wagons." Apparently, the Saints had also contracted a large number of handcarts to be made in St. Louis. The previous year, an article in the Davenport Daily Gazette, 2/15/1856, drawing from the St. Louis Republican, reported that "an establishment in this city [St. Louis] has received an order, and are now manufacturing about five hundred of these vehicles," which the item called "wheelbarrows." The person making the handcarts was probably Louis Espenschied, a German immigrant who had moved to St. Louis in 1840. The Saints had been working with Espenschied as early as 1853, when St. Louis Mormon emigration agent Horace Eldredge purchased 14 wagons at \$58 apiece from Espenschied to help outfit the Saints who were gathering to Keokuk, Iowa, for their trek west. See Fred E. Woods and Douglas Atterberg, "The 1853 Mormon Migration through Keokuk," Annals of Iowa 61 (2002), 10. See also Erastus Snow to Brigham Young, 2/14/1857, LDS Church Archives 
Some incoming LDS emigrants in 1856 may have lodged in the railroad building before proceeding to the Mormon campground. One Mormon convert who had crossed the Atlantic on the Enoch Train recalled, "We arrived in Iowa City about 9 p.m. met the other part of our company at the railroad storehouse at which place we sheltered." 54 Yet when a large company of Saints who had disembarked from the ship Horizon arrived in Iowa City, Heber Robert McBride remembered, "There was no place at the depot large enough to accomodate so many people. So a great many of the people started for camp on foot just about dark and I was one of them." Fortunately for McBride, his fellow Saints had kept "a big fire burning for to let the people know where the camp was." 55

Having gathered at the campground where the main body of the Saints was assembled, decisions were made as to when individuals and companies would be able to depart. Those decisions depended on the readiness of the companies' handcarts and emigrants' assessment of whether they had the necessary funds to outfit a trip across the Plains for themselves and their families. Many Saints apparently chose to obtain temporary employment in Iowa City, regardless of whether they had the means to continue the journey. Most knew they could use the extra money and did not want to squander their time waiting for departure.

Some who worked for a few days in the Iowa City area were tempted to delay their journey onward to the Salt Lake Valley due to the high wages being offered. Edmund Ellsworth recalled,

At Iowa City, before the handcarts were ready, some of the brethren and sisters began to despair of ever accomplishing so long a journey; and the inhabitants of the surrounding country offered them great wages; telling them that if they remained there and

54. Andrew Smith, Journal, 5/12/1856. The temporary shelter for the Mormon emigrants (and likely other migrants) seems to have been a common courtesy provided by the railroad. While passing through Rock Island, Illinois, on May 10, 1856, Latter-day Saint migrant John D. T. McAllister wrote, "Moved the company to a large commission house, kindly loaned by the Railway Company." John Daniel Thompson McAllister, Journal, 5/10/1856, LDS Church Archives. See also Iowa City Republican, 6/23/1856.

55. Heber Robert McBride, Autobiography, 8. 
served them one year, that without doubt they could earn a good team and wagon, and a cow or two, and then they could cross the plains with comparative ease. This had its effect upon some few at Iowa city, and there were a few who had to be considerably persuaded to start from that place.

Priscilla Merriman Evans, who had crossed the ocean on the Samuel Curling in 1856 remembered that she and her family spent three weeks in Iowa City, waiting for their handcarts to be completed. During that time, she explains, "We were offered many inducements to remain there. My husband was offered ten dollars per day to stay and work at his trade of iron roller. But money was no inducement, as we were anxious to go to Zion." Similarly, Louisa Mellor recalled, "we remained in Iowa City from July 8 to July 28, 1856, where my father secured work, and with the means was able to buy two handcarts and some food and clothes to make the journey across the plains." Others were less fortunate. Elizabeth Sermon, who passed through Iowa City in the summer of 1856, wrote, "We arrived in Iowa and a number of us rented a house at twenty dollars per month. ... My husband ... got some work to do at $\$ 1.00$ per day." Evans also noted that some of those who remained to improve their circumstances "died of cholera and many apostatized from the church." 56

Some of the women also found opportunities to earn money to cover expenses. Mary Brannigan Crandell recollected, "while waiting for the handcarts to be finished, three or four of us went to Florence [Iowa] a beautiful little place, about six miles from Iowa City, to see if we could get some sewing to do. . . . A lady by the name of Johnson engaged me at five dollars a week, and my board, the other girls got more. . . . I cut and made dresses for the lady and taught one of her boys to write." Crandell soon made friends with the Johnson family, who, Crandell noted, "treated me like their own daughter." Eventually Mrs. Johnson asked her, "What will you do hauling a handcart across the plains? Why your hands will be blistered the first day, and you

56. "Account of His Mission," Deseret News, 10/8/1856; Priscilla Merriman Evans, Autobiography, 39; Elizabeth Sermon (who crossed the Atlantic on the Caravan), Autobiography, 2, LDS Church Archives; Louisa Mellor Clark, Autobiography, in Carter, comp., Our Pioneer Heritage, 17: 304, 306. 
have never been accustomed to hard work." Crandell responded, "Dear lady I know you are interested in me and I feel grateful for your kindness, but I shall try it." 57

Not all of the young women were as strong-spirited as Crandell. On May 19, 1856, according to the Davenport Daily Gazette, "some of the women among the company of English Mormons that passed our city last week were faint-hearted and wish to turn back." Towards the end of the following month the same newspaper noted, "We understand that while they [the Mormon emigrants] were in Rock Island, several of the ignorant and deluded creatures manifested a disposition to desert, having no desire to push the wheel barrow [handcart] over the farstretching prairies at this season of the year." 58

One young woman who seems to fit such a description was Elizabeth "Betsy" Edwards, who is listed in immigration records as a 20-year-old "spinster." Edwards was one of about 700 British Saints (many of them Welsh) who crossed the Atlantic in 1856 on the Samuel Curling under the direction of the famous LDS Welshman, Captain Dan Jones. ${ }^{59}$ According to Elizabeth Dennis, Jones and his company camped on the Dennis farm, "on the banks of Clear Creek, ... three miles west of Iowa City." Dennis claimed that while she had gone to town, Edwards had rushed up to Dennis's father, who was watching the farm, and said, "I am from the Mormon camp, and they are going to start west in three days and I do not want to go with them. Can you direct me to a good family who wish to secure a girl to help them with their house work?" "Yes," replied the father, "my daughter will be glad to take you." Jones sent a group of Mormon men to bring her back, resulting in a ten-day standoff before the Mormon handcart company finally moved on. Dennis claimed that Edwards stayed and later married a local bachelor by the name of John Shipton. 60

57. Crandell, "Autobiography of a Noble Woman," 319.

58. Davenport Daily Gazette, 5/19/1856 and 6/27/1856.

59. Deseret News 1997-98 Church Almanac, 161. See also the Mormon Immigration Index under the section listing passengers aboard the vessel Samuel Curling.

60. Mrs. Isaac Dennis, "Mormon Pioneer Story," in a document prepared by Coralville centennial officials titled "Centennial Year 1973, Coralville, Iowa," 22-23, housed at the State Historical Society of Iowa, Iowa City. Isaac Dennis 
Elizabeth Edwards's obituary tells a different version of the story, claiming that "her escape from camp was wisely planned" after another of "the discontented ones ... , a long time friend of Elizabeth's, . . f found a home and staunch friends with strangers, in a strangely new land." The obituary also intimates that anticipation of the long journey by handcart was not Edwards's primary cause for defection: "Before the company reached mid-ocean the beauty and glamor of the new religion had vanished. The slightest hint of polygamy had never been mentioned in Wales. By the time Iowa City was reached a well defined spirit of restless homesickness for the old homes, the faith of their fathers possessed the hearts of the Welsh converts, and Elizabeth Edwards was one of those who decided to abandon the further trip across the plains." The obituary adds, "Though Elder Jones discovered her new abiding place, and used every persuasion for her return, that his fatherly kindness would permit - with gratitude for all his past kindness - and only a most desolate look to the future, she remained firm in her resolution, as time after time they came to her with entreaties and warnings." 61

Although a few emigrants chose to remain behind, the vast majority who made it to Iowa City began their journey to the Salt Lake Valley after a temporary stay of a few weeks. ${ }^{62} \mathrm{How}-$

had settled in Iowa with his parents in 1838. Five years later he married Elizabeth Fellows, and they had six children. History of Johnson County, Iowa (Iowa City, 1883), 807-8. For more biographical information on the Isaac Dennis family, see Charles [sic, i.e., Clarence] Ray Aurner, Leading Events in Johnson County Iowa History, 2 vols. (Cedar Rapids, 1913), 2:844-52.

61. Marengo Republican, 8/21/1912. Elizabeth Edwards was related to Jones, had lived in the same house with him in Swansea, Wales, for two years, and acknowledged his "unvarying fatherly kindness and fine personality." Ibid. The History of Iowa County, Iowa (Des Moines, 1881), 756, confirms that John Shipton did indeed marry Elizabeth Edwards in March 1857, when John was 36 years old and Elizabeth 18. They had seven children. In 1860, according to the 1860 Iowa Census, John Shipton was living and farming in Clear Creek Township, Johnson County, Iowa, with his wife, Elizabeth. With real estate valued at $\$ 1,600$, it appears that the Shipton family was relatively prosperous. Elizabeth had been a widow for three years when she died in Marengo Township, Iowa County, at the age of 73 on August 7, 1912. Register of Deaths for Iowa County, Book 3 (1911), 18, Iowa County Courthouse, Marengo.

62. After reaching the United States, a few other women left Mormon emigrant companies along the route to Utah. For example, James G. Willie Emigrating 
ever, financial difficulties compelled a few of the Saints to linger for a season. Such was the case of Samuel Handy, who provides a useful sketch of what life was like for Mormons who remained in Iowa City in 1857:

At Iowa City we found a branch of the Church, presided over by a man named William Williams - during our stay in this place John Taylor succeeded Brother Williams in presiding over the Iowa City Branch. Edwin Stratford, three Brother Taylors and others, with their families made quite a nice little branch of the Church. I went to work immediately on my arrival, and got $\$ 1.25$ per day and my dinner all through the summer, and in the winter I carried the buck \& saw \& sawed wood and made about 75 cents per day - some days only 50 cents and some days I was idle. We paid some 2, 3, and sometimes 4 dollars a month rent while we were at Iowa City. My wife went washing while we lived there and assisted considerably in getting our outfit for Utah.

Two years later, Handy and his family joined a Mormon company heading west to the Salt Lake Valley. ${ }^{63}$

Company, Journal, LDS Church Archives, 7/20/1856, notes, “Yesterday Sister Adelaide A. Baker left us \& this morning came and took her luggage \& two of her children away with her . . . ; also Ann \& Sabrina Bird . . left us this day." History of Iowa County, Iowa (Des Moines, 1881), 734, notes, "Two young men of Iowa County became enamored of two Mormon girls, whom they chanced to meet at the Mormon camp. The young men's love was reciprocated, and by stealth they left the camp of the 'Saints' at night, were married, and now each couple has a large and highly respected family." The Marriage Record Book, A-B, Iowa County, pp. 53 and 63, at the Iowa County Courthouse in Marengo confirms that "Edwin D. Smith and Sabina Bird received a marriage license April 12 1857" and that "Milo Mitchell and Ann Bird received marriage license Oct 12th 1857." The History of Johnson County (Iowa City, 1883), 614, also mentions, "On one occasion three young girls were discovered to be dissatisfied and parties assisted them to escape from the Mormon company. One of the girls returned to England, the other two married and settled in Iowa." Harriet Smith appears to be the one who returned to her native homeland. Elizabeth "Betsy" Edwards is likely the woman who was assisted in her desire to remain in the Iowa City vicinity. I am grateful to Iowa City residents Gerry and Marilyn Gaffey, as well as Ali Pili (Marilyn's sister), for their assistance in researching the story of these young women who abandoned the Mormon trek to Utah.

63. Samuel Handy, Autobiography, Special Collections, Utah State University Library, 13-14. Samuel Handy and his family crossed the Plains in 1859 with the James S. Brown company. See http://lds.org/churchhistory/library/ pioneercompany/0,15797,4017-1-73,00.html. 
FOR MORMON EUROPEAN CONVERTS who gathered to Utah in 1856 and 1857, the arduous trip included thousands of maritime miles and hundreds more by rail to reach the frontier outfitting post of Iowa City, where handcarts were used to complete their journey. The Crimean War and harsh winter weather conditions interfered with the availability of sailing vessels during the 1856 season and affected arrangements for ocean travel. While the Atlantic crossing was lengthy, trustworthy Mormon leaders worked hard to make the experience as pleasant as possible regardless of the conduct of mariners whose behavior was at times as unpredictable as the weather. In the face of health hazards and occasional encounters with storms, most of the Saints assisted one another. Sewing tents as well as wagon and handcart covers also created a seam of companionship among the European converts. Frequent religious meetings as well as recreational activities, such as games, song, and dance, forged an optimistic attitude that eased the journey. Upon reaching the Eastern seaboard, competent Mormon emigration agents arranged for rail transportation and temporary employment as needed. Although rail travel was uncomfortable and at times dangerous, skilled agents successfully negotiated the lowest fares possible.

For a few fainthearted converts, the prospect of the long trip by foot with handcarts proved too daunting, and they chose to remain permanently somewhere in Iowa. Financial difficulties also compelled a few of the faithful Saints to remain behind for a season. For those who continued on, passage to the promised land required stamina and exertion, and some paid dearly with their very lives. Yet most completed the journey successfully. As evidenced in dozens of journals, those who made the effort to reach Salt Lake found the price to gather well worth paying. The handcart experience launched in Iowa City continues to be an important chapter in the Mormon migration saga, but the significance of the journey by sail and rail to arrive at that point should not be overlooked. 